Note

\section{Purification and Some Properties of a Glucoamylase from Clostridium sp. G0005}

\author{
Hiroshi OHNishi, Hiroshi SAKaI \\ and Takahisa OHTA \\ Department of Agricultural Chemistry, \\ The University of Tokyo, \\ Bunkyo-ku, Tokyo 113, Japan
}

Received January 21, 1991

Glucoamylase $[1,4 ; 1,6-\alpha$-D-glucanglucohydrase, EC 3.2.1.3] catalyzes the release of $\beta$-D-glucose from the non-reducing ends of starch and related polysaccharides. Most of the reported glucoamylases are fungal or yeast enzymes. ${ }^{1-8)}$ Ishida et al. (Hitachi Research Laboratory, Hitachi, Ltd.) found a glucoamylase activity from an anaerobic thermophilic bacterium, Clostridium sp. G0005, ${ }^{9)}$ and we purified the enzyme to homogeneity. Glucoamylase activity was assayed by incubation in $125 \mathrm{mM}$ sodium acetate buffer, $\mathrm{pH} 4.5$, for 15 or $30 \mathrm{~min}$ at $60^{\circ} \mathrm{C}$ in the presence of $0.5 \%$ soluble potato starch (Sigma) as substrate. Glucose concentration of the incubated solution was measured by using a glucose analyzer (model 23, Yellow Springs Instrument Co., Inc. Yellow Springs, Ohio 45387). One unit of activity corresponds to the formation of $1 \mu \mathrm{mol}$ of glucose per minute. Clostridium sp. G0005 was cultured in a medium containing (per litter): dextrin, $15 \mathrm{~g}$; peptone, $5 \mathrm{~g}$; yeast extract, $5 \mathrm{~g} ; \mathrm{KH}_{2} \mathrm{PO}_{4}, 7 \mathrm{~g} ; \mathrm{Na}_{2} \mathrm{HPO}_{4}, 3.5 \mathrm{~g} ; \mathrm{MgSO}_{4}, 0.1 \mathrm{~g}$; sodium thioglycolate, $1 \mathrm{~g}$; and resazurin, $0.2 \mathrm{~g}$ (as an oxidation-reduction indicator), under strictly anaerobic conditions with $\mathrm{N}_{2}$. Cultures were agitated at 200 to $250 \mathrm{rpm}$ at $60^{\circ} \mathrm{C}$. Glucoamylase activity was detected both in cells and in the medium. Both glucoamylase activities were increasing during log-phase in cell growth and reached a maximum at stationary phase. Glucoamylase activity of cells was 2.5-3-fold larger than the activity in the medium at stationary phase. Washed intact cells of Clostridium sp. G0005 showed glucoamylase activity and the cellassociated glucoamylase activity was solubilized by repeated sonication, the total activity being kept constant in the course of the operation (Fig. 1). The activity was also released from the cells by freezing and thawing of the cells. These resuits suggested that all of cell-associated glucoamylase (CGA) is located on the cell surface and its active site faces toward the outside. This characteristic localization of the enzyme is similar to that of glucoamylase and pullulanase activities in Clostridium thermohydrosulfuricum. ${ }^{10,11)}$
CGA was purified from cells of Clostridium sp. G0005. Forty liters of full growth culture were centrifuged at $7,000 \times g$, separating the medium and cells. Harvested cells $\left(50 \mathrm{~g}\right.$, wet weight) were frozen at $-20^{\circ} \mathrm{C}$, then thawed at room temperature and washed with $100 \mathrm{ml}$ of $20 \mathrm{~mm}$ sodium phosphate buffer, $\mathrm{pH} 7.0$, containing $0.1 \mathrm{M} \mathrm{KCl}$, $1 \mathrm{~mm}$ PMSF, and $1 \mathrm{~mm}$ EDTA. Cells were removed by centrifugation at $10,000 \times g$ for $30 \mathrm{~min}$ and resuspended in the same buffer. Five hundred $\mathrm{ml}$ of the supernatant, collected by repeated extraction, was adjusted to $40 \%$ saturation of $\left(\mathrm{NH}_{4}\right)_{2} \mathrm{SO}_{4}$ and put on a column of Butyl-Toyopearl 650M (Tosoh Corp.). An active fraction was separated from the column with a decreasing linear gradient of 40 to $0 \%$ saturation of $\left(\mathrm{NH}_{4}\right)_{2} \mathrm{SO}_{4}$ in buffer A ( 25 mm sodium phosphate buffer, $\mathrm{pH} 7.0$ ). After dialysis against buffer B ( $20 \mathrm{~mm}$ Tris-Cl buffer, $\mathrm{pH} 7.0$ ), the enzyme fraction was further purified by a column of MonoQ HR $10 / 10$ (Pharmacia) with a linear gradient of 0 to $0.5 \mathrm{M} \mathrm{KCl}$ in buffer B. Active fractions, eluted at $50-100 \mathrm{~mm} \mathrm{KCl}$, were put on a column of Butyl-Toyopearl 650S (Tosoh Corp.) and that of MonoQ HR 5/5 (Pharmacia) successively under the buffer conditions described above. This final purified enzyme was $1.8 \mathrm{mg}$, and gave a single band on SDS-polyacrylamide gel electrophoresis ${ }^{12,13)}$ and had a molecular weight of 77,000 . Specific activity of CGA was $66 \mathrm{U} / \mathrm{mg}$. Protein was measured by the method of Bradford ${ }^{14)}$ using bovine serum albumin as a standard.

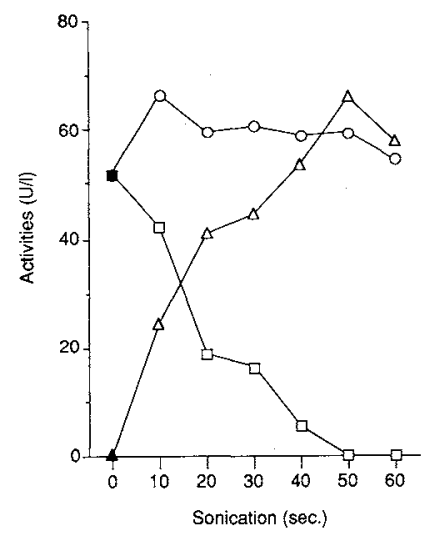

Fig. 1. Solubilization of CGA by Sonication.

One $\mathrm{ml}$ and a half of a full growth culture of Clostridium sp. G0005 was centrifuged at $17,000 \times g$ for $5 \mathrm{~min}$. The harvested cells were washed with $20 \mathrm{mM}$ Tris-Cl buffer, $\mathrm{pH} 7.0$ and suspended in $1.5 \mathrm{ml}$ of the same buffer. The cell suspension was sonicated for $10 \sec 6$ times. After measurement of glucoamylase activity of the sonicated sample (circles), the suspension was centrifuged at $17,000 \times g$ for $5 \mathrm{~min}$. The precipitant was resuspended in $1.5 \mathrm{ml}$ of the same buffer. Glucoamylase activity of the supernatant fraction (triangles) and the suspension of the precipitant (squares) was measured. Solid symbols show the measurements of intact cells. 

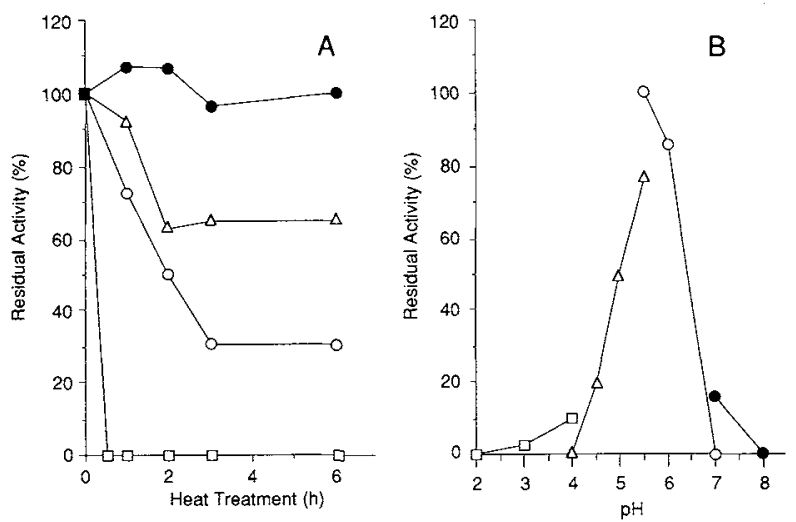

Fig. 2. Thermal stability of activity (A) and pH dependence of thermal stability (B) of CGA.

A, CGA $(22.7 \mu \mathrm{g} / \mathrm{ml})$ was incubated in $125 \mathrm{~mm}$ sodium acetate buffer $(\mathrm{pH} 4.5)$ at $60^{\circ} \mathrm{C}$ (solid circles), $65^{\circ} \mathrm{C}$ (triangles), $70^{\circ} \mathrm{C}$ (open circles) and $80^{\circ} \mathrm{C}$ (squares), for the indicated length of time. Then a sample of the enzyme was removed for assay. B, CGA $(3.8 \mu \mathrm{g}$ protein $/ \mathrm{ml})$ was incubated at $70^{\circ} \mathrm{C}$ for $1 \mathrm{hr}$ at various $\mathrm{pH}$ in $125 \mathrm{~mm}$ glycine-HCl (squares), sodium acetate (triangles), MES-NaOH (circles), and $50 \mathrm{~mm}$ sodium phosphate (solid circles) buffers. Residual activities were measured.

The $\mathrm{N}$-terminal amino acids of the CGA preparation were analyzed by a gas phase protein sequencer (Model 470A, Applied Biosystems Japan, Ltd.) and PTH-analyzer (Model 120A, Applied Biosystems Japan, Ltd.). No PTH amino acids were detected in significant amounts. The $\mathrm{N}$-terminal of the protein was supposed to be modified. A glucoamylase found in the culture supernatant was also purified in the same manner and showed similar properties to the enzyme described above.

The temperature and $\mathrm{pH}$ dependence of CGA activity was investigated at various temperatures from 30 to $80^{\circ} \mathrm{C}$ in $125 \mathrm{~mm}$ sodium acetate buffer at $\mathrm{pH} 4.5$, and at different $\mathrm{pH}$, from 2 to 8 at $60^{\circ} \mathrm{C}$ using $125 \mathrm{~mm}$ glycine- $\mathrm{HCl}$ buffer $(\mathrm{pH} 2.0-4.0), 125 \mathrm{~mm}$ sodium acetate buffer $(\mathrm{pH} 3.5-5.5)$, $125 \mathrm{~mm}$ MES- $\mathrm{NaOH}$ buffer (pH $5.5-7.0)$, and $50 \mathrm{~mm}$ sodium phosphate buffer (pH 7.0-8.0). The CGA concentration in these assays were $0.3 \mu \mathrm{g}$ protein $/ \mathrm{ml}$. The optimal temperature and $\mathrm{pH}$ for the enzyme were $65^{\circ} \mathrm{C}$ and $\mathrm{pH} 4.5$. The thermal stability of $\mathrm{CGA}$ at $\mathrm{pH} 4.5$ was measured (Fig. 2A). CGA was stable at $60^{\circ} \mathrm{C}$ but was inactivated above $65^{\circ} \mathrm{C}$. To test the effects of $\mathrm{pH}$ on thermal stability, CGA was incubated at $70^{\circ} \mathrm{C}$ in various $\mathrm{pH}$ (Fig. $2 \mathrm{~B})$. The enzyme activity was lost abruptly at $\mathrm{pH}$ below 4 and above 7 .

In this study, we purified a new bacterial glucoamylase, of which characteristics were similar to fungal and yeast glucoamylases. ${ }^{15)}$ Further analysis of the enzyme and comparison with other glucoamylases are expected to provide a lot of suggestions to elucidate the mechanism of the glucoamylase reaction.

\section{References}

1) T. Takahashi, Y. Tsuchida and M. Irie, J. Biochem., 84, 1183 (1978).

2) N. Inokuchi, T. Takahashi and M. Irie, J. Biochem., 90, 1055 (1981).

3) T. Takahashi, N. Inokuchi and M. Irie, J. Biochem., 89, 125 (1980).

4) W. Kanlayakrit, K. Ishimatsu, M. Nakao and S. Hayashida, J. Ferment. Technol., 65, 379 (1987).

5) I. Yamashita, K. Suzuki and S. Fukui, J. Bacteriol., 161, 567 (1985).

6) Y. Tanaka, T. Ashikari, N. Nakamura, N. Kiuchi, Y. Shibano, T. Amachi and H. Yoshizumi, Agric. Biol. Chem., 50, 965 (1986).

7) S. Ueda, R. Ohba and S. Kano, Starch, 26, 374 (1974).

8) Y. Yamasaki, Y. Suzuki and Ozawa, Agric. Biol. Chem., 41, 2149 (1977).

9) M. Tuchiya, R. Haga and M. Ishida, Japan Kokai Tokkyo Koho, 379 (Feb. 20, 1988).

10) H. H. Hyun and J. G. Zeikus, Appl. Environ. Microbiol., 49, 1168 (1985).

11) H. H. Hyun and J. G. Zeikus, J. Bacteriol., 164, 1146 (1985).

12) U. K. Laemmli, Nature, 227, 680 (1970).

13) K. Weber and M. Osborn, J. Biol. Chem., 224, 4406 (1969).

14) M. M. Bradford, Anal. Biochem., 72, 248 (1976).

15) M. Vihinen and P. Mantsala, Critical Reviews in Biochemistry and Molecular Biology, 24, 329 (1989). 